\title{
THE TOXIC FACTORS IN EXPERIMENTAL TRAUMATIC SHOCK. V. CHEMICAL AND ENZYMATIC PROPERTIES OF MUSCLE EXUDATE ${ }^{1}$
}

\author{
By P. C. ZAMECNIK, J. C. AUB, A. M. BRUES, S. S. KETY, I. T. NATHANSON, \\ A. L. NUTT, AND A. POPE \\ (From the Medical Laboratories of the Collis P. Huntington Memorial Hospital of \\ Harvard University at the Massachusetts General Hospital, Boston, Massachusetts)
}

(Received for publication April 9, 1945)

Studies of the pharmacologic effects of exudates from traumatized limbs have been made by several workers $(30,69)$. Detailed studies have been lacking, however, on the chemical nature of exudates from anoxic or traumatized tissues. The technique of muscle tying previously described (14) has afforded an opportunity for collecting the exudate from a well-circumscribed set of muscles after a period of anoxia and trauma. This exudate, in amounts which ranged up to $480 \mathrm{ml}$., accumulated in the first $51 / 2$ hours after release of a constricting band which had produced anoxia for 5 hours.

We have studied, therefore, in some detail the chemical properties of muscle exudates obtained from single animals, as well as the properties of a pooled collection of muscle exudates from a group of 9 dogs. The central problem which has concerned us has been to determine the type of substance responsible for the toxic effects of certain muscle exudates.

\section{MATERIALS AND METHODS ${ }^{2}$}

All animals were anesthetized as described previously (14). In the enzymatic experiments a modification of the Grassmann-Heyde (73) titration technique was used, $0.2 \mathrm{ml}$. aliquots of test solution being titrated against 0.01 $\mathrm{N}$ alcoholic potassium hydroxide in a 90 per cent alcoholic medium, with $1: 10,000$ thymolphthalein as an indicator. It was necessary in some cases to titrate aliquots of test solution containing up to $3 \mathrm{mgm}$. protein nitrogen per $\mathrm{ml}$. In these instances, a heavy protein precipitate appeared in the 90 per cent alcoholic titration medium, and the resultant turbidity interfered with the precision of the end-

1 This is reprint No. 609 of the Cancer Commission of Harvard University.

The work described in this paper was done under a contract, recommended by the Committee on Medical Research, between the Office of Scientific Research and Development and the Massachusetts General Hospital.

2 See acknowledgments. point determination. It was found possible to obtain a satisfactory endpoint color change, nevertheless, if $0.2 \mathrm{ml}$. of 1 per cent thymolphthalein in absolute ethanol was used as an indicator in a titration medium containing, in addition, $0.2 \mathrm{ml}$. of test solution and $1.8 \mathrm{ml}$. of absolute ethanol.

The ammonium sulfate fractionations were made in the following way. The ammonium sulfate solution of the desired concentration was placed in a 12-liter cylinder and was dialyzed overnight at $2.5^{\circ} \mathrm{C}$. into a rotating cellophane bag containing the muscle exudate, a technique in principle similar to that used by McMeekin (74). The precipitate was resuspended in 1 per cent sodium chloride and was dialyzed in a rotating cellophane bag against frequent changes of 1 per cent sodium chloride over the following 24-hour period until the ammonium sulfate was thoroughly dialyzed out.

The preparation of the aminoexopeptidase from normal dog muscle was made as follows. Five hundred and seventy-five grams of thigh muscle were obtained from a freshly killed dog and were frozen immediately on carbon dioxide snow. One week later the muscle was thawed, ground, and extracted at $2.5^{\circ} \mathrm{C}$. for 3 hours with 2 volumes of 1 per cent sodium chloride and in the presence of toluene. All further procedures were carried out in the cold room at $2.5^{\circ} \mathrm{C}$. The preparation was squeezed through cheese cloth, then made 0.4 saturated with ammonium sulfate by careful addition of the solid salt. The $\mathrm{pH}$ was 6.0. After standing overnight, it was filtered through a Buchner funnel with Whatman number 1 paper and Hyflo Supercel. The filtrate was then made up to 0.7 saturation with ammonium sulfate and allowed to stand overnight. The preparation was filtered though a Buchner funnel with number 5 Whatman paper, and the precipitate was dissolved in $140 \mathrm{ml}$. of 1 per cent sodium chloride.. After 2 days' dialysis against 1 per cent sodium chloride, the solution was tested against 1-leucylglycylglycine and found to be active $(C=0.03)$. This order of activity represents a 10 -fold increase over that of crude muscle. Adjustment of the $\mathrm{pH}$ of the muscle extract to pH 4 resulted in a marked loss of enzymatic activity. Lesser concentrations of enzymatic activity were found in the precipitates between 0 and 0.4 saturation $(C=0.003)$ and above 0.7 saturation $(C=0.0001)$ with ammonium sulfate. The enzymatic activity, therefore, is precipitated out principally between 0.4 and $0.7 \cdot$ ammonium sulfate saturation. 


\section{EXPERIMENTAL}

As a first step in the problem the chemical anatomy of this muscle exudate was studied. The observations consist of (A) a study of the electrolyte pattern of the fluid, and (B) a study of the protein constituents of the fluid by means of (1) electrophoresis, (2) dialysis, (3) fractionation of the muscle exudate proteins, and (4) study of proteolytic enzymes.

The exudate as it drained from the muscles was light red in color, odorless, with a hematocrit around 1 per cent, a specific gravity of 1.018 , and a tendency to form a very thin clot. The fluid was collected in sterile flasks surrounded by ice. Following centrifugation the clear, practically cellfree, supernatant fluid was used for further experiments. The supernatant fluid was frequently preserved on carbon dioxide snow between the time of collection and the time of administration to another animal without noticeable change in its pharmacologic action.

In spite of employment of sterile techniques in operation and collection, the fluid contained bacteria in all experiments in which a search was made for their presence. A study of the rôle of bacteria in the production of shock by these muscle exudates has already been reported from this laboratory $(10,75)$.

\section{A. Electrolyte studies}

Figure 1 shows the electrolyte composition of pooled muscle exudate (fluid number 9) as compared with the electrolyte content of normal dog serum and lymph as compiled by Drinker and Yoffey (76). The conventions used are those originated by Gamble (77). This pooled muscle exudate produced shock in 2 dogs when injected intravenously ( $15 \mathrm{ml}$. per $\mathrm{kgm}$ ).

Muscle exudate differs from serum in the following particulars:

1. The total electrolyte concentration in muscle exudiate is lower.

2. The $\mathrm{pH}$ of muscle exudate is lower, ranging from 7.0 to 7.2 in individual exudates.

3. The total protein concentration of muscle exudate is lower.

4. There is considerable hemolyzed blood, from 2.5 per cent present in the muscle exudates studied, as evidenced by a cherry-red color and a hemogloblin concentration ranging from 0.3 to 0.8 grams per cent in different preparations. It is highly probable that myoglobin contributes to this color. No attempt has been made to distinguish between these 2 globins.

5. The potassium and inorganic phosphate $\left(\mathrm{HPO}_{4}=\right)$ concentrations of muscle exudate are increased.

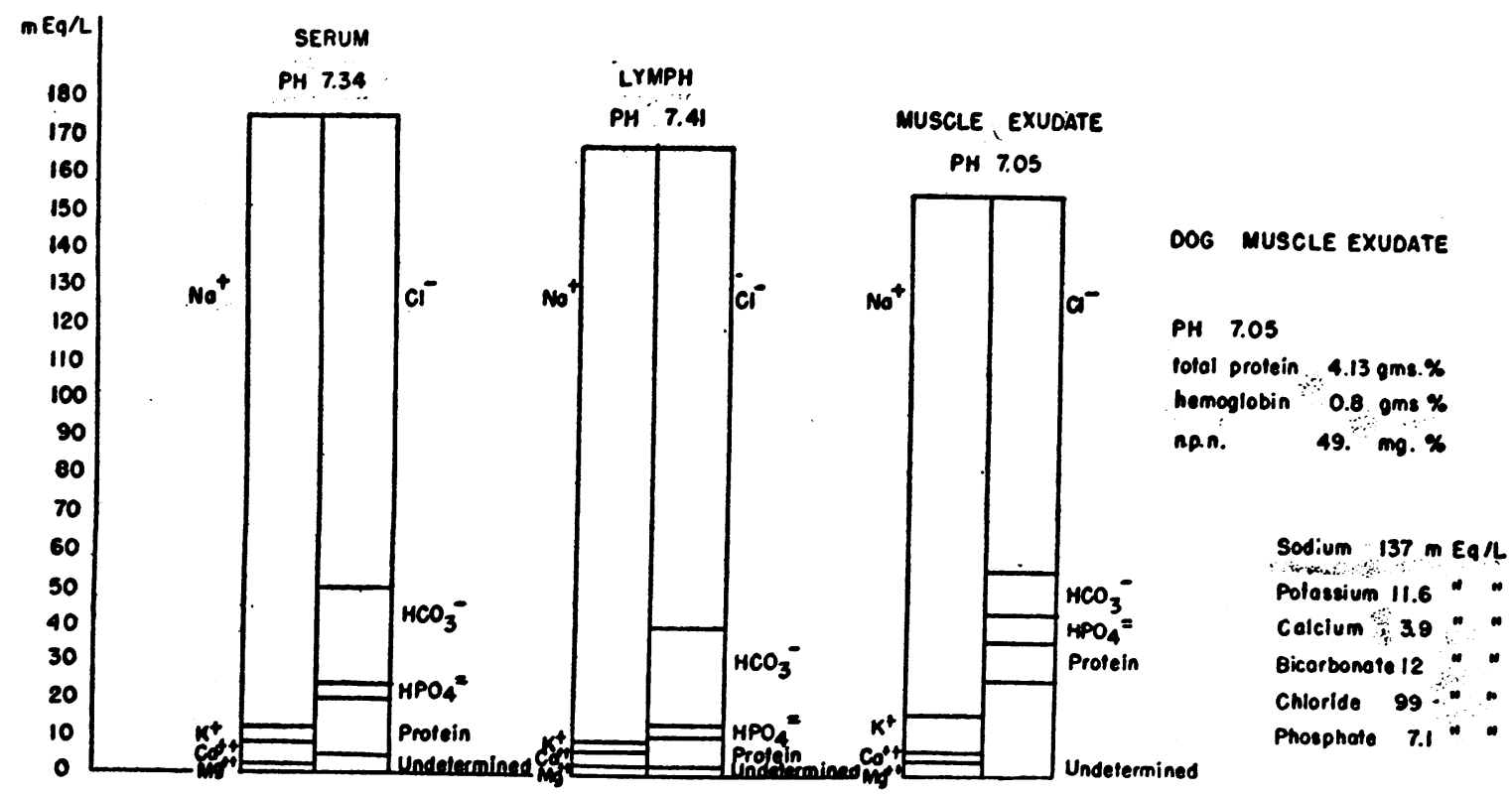

Fig. 1. Comparison of the Electrolyte Composition of Dog Serum, Lymph, and Muscle Exudate 
6. Muscle exudate contains less calcium than would be expected were it derived from plasma alone, even when the diminshed protein content of muscle exudate is taken into account. Data on lymph (76) show calcium levels of 9 to $12 \mathrm{mgm}$. per cent, which are likewise higher than the muscle exudate level. In 2 individual experiments, the concentrations of calcium in the terminal serum were 11.5 and $10.9 \mathrm{mgm}$. per cent, while in the muscle exudates from the same animals they were 7.2 and $6.0 \mathrm{mgm}$. per cent, respectively.

7. The bicarbonate concentration of the muscle exudate is markedly decreased and the chloride concentration is somewhat diminished, resulting in an increase in total undetermined anions. In individual exudates the bicarbonate concentration has been as low as 6 millimoles per liter.

The findings of high potassium and inorganic phosphate concentrations indicate a breakdown of muscle cells, a leakage out of these intracellular ions, and perhaps decomposition of organic phosphate. They are consistent with analysis of potassium and chloride concentrations of fluid obtained from the subcutaneous tissue of a traumatized area (6). The decrease in the bicarbonate concentration and in total accountable anions in the presence of a lowered $\mathrm{pH}$ value points to an increase in undetermined organic acids, formed in part as a result of the anaerobic metabolism of the muscle.

\section{B. Study of protein constituents}

1. Electrophoresis. The electrophoretic patterns of a single muscle exudate, fluid number 117, have been compared with the patterns of plasma from the same dog before and after the muscletying and draining procedure. ${ }^{8}$ Electrophoresis was carried out in a phosphate buffer of $\mathrm{pH} 7.7$, and ionic strength 0.2 , at $1.5^{\circ} \mathrm{C}$., over a 4-hour period, at a potential gradient of 4 volts per $\mathrm{cm}$. Figure 2 shows tracings obtained from the electrophoretic patterns. It demonstrates that in the muscle exudate the fraction migrating with the same velocity as the gamma globulin fraction of plasma is increased considerably, and the alpha globulin fraction is decreased. The increase in the slowest-moving component suggests that in muscle

\footnotetext{
3 For these electrophoretic patterns and their interpretations the authors are indebted to Dr. Gertrude E. Perlmann, of the Massachusetts General Hospital.
}

Dog 117
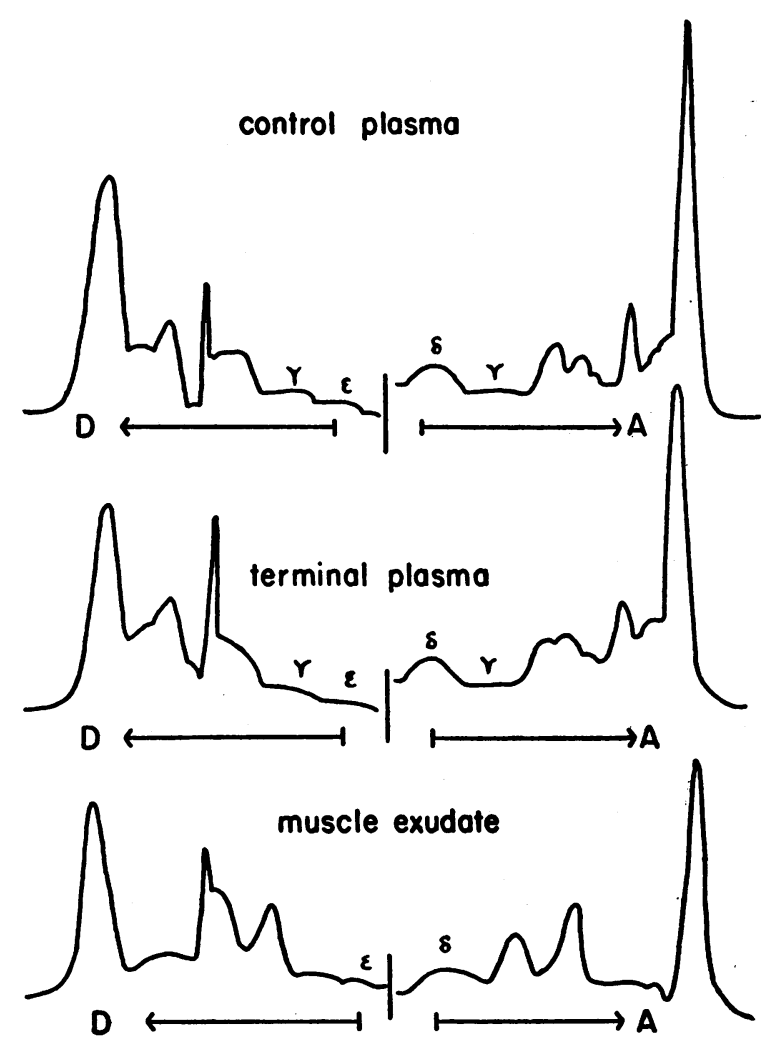

Fig. 2. Tractings of Electrophoretic Patterns of Plasma and Muscle Exudate

protein breakdown, proteins of electrophoretic properties similar to those of the gamma globulins of plasma make their appearance in the muscle exudate.

During the course of this experiment, there was a drop of plasma protein from a level of 7.0 grams per cent at the beginning to 5.0 grams per cent at the end of the experiment. The protein in the muscle exudate can conceivably be accounted for as coming largely from plasma. ${ }^{4}$ The electrophoretic patterns of plasma indicate a decrease in the relative concentration of albumin from the control plasma to the terminal plasma. The albumin: globulin ratio as calculated from the electrophoretic patterns changed from 0.9 to 0.7 during the course of the experiment.

4 Thus, in one experiment, even if the assumption is made that the plasma volume was not reduced during the course of the experiment, 25 grams of protein were lost from the plasma protein, and $14^{\circ}$ grams of protein were found in the muscle exudate. 
2. Dialysis studies. After dialysis of the muscle exudate (fluid number 9) through Visking cellulose tubing, 0.0008 inch wall thickness, for 24 to 48 hours against changes of distilled water or 1 per cent sodium chloride at $2.5^{\circ} \mathrm{C}$., it was found that the pharmacologically-active fraction was nondialyzable. This non-dialyzable material was lyophilized in a Flosdorf-Mudd (78) apparatus, and the dry powder, re-dissolved in 1 per cent sodium chloride, was shown still to possess its shock-producing properties. This evidence rules out as possible major toxic agents a good many low molecular weight, dialyzable organic substances which might be present as a result of proteolysis or of the anaerobic metabolism of muscle. Although this evidence does not deny the possibility of adsorption of small molecular weight substances onto protein molecules, it does serve to focus attention on particles of large molecular size or aggregation.

3. Fractionation studies. A collection of muscle exudates (termed fluid number 9) was made from 9 dogs, using aseptic techniques, and freezing each exudate on carbon dioxide snow immediately after collection. The individual exudates were then thawed and pooled, amounting to $2100 \mathrm{ml}$. of fluid which was refrozen in $100 \mathrm{ml}$. lustroid containers. Assay of aliquots of this fluid in 2 dogs (numbers 122 and 123 ) resulted in typical shock (25). The remainder of the pooled fluid was subjected to fractionation procedures. Dialysis of a $150 \mathrm{ml}$. aliquot against 1 per cent sodium chloride for 18 hours at $2.5^{\circ} \mathrm{C}$. revealed (dog 128) that the activity remained in the non-dialyzable portion. Another $150 \mathrm{ml}$. aliquot was dialyzed against 3 changes of $150 \mathrm{ml}$. each of distilled water for 18 hours at $2.5^{\circ} \mathrm{C}$. Seven-eighths of the dialyzable material, therefore, was theoretically dialyzed out. Both the dialyzable and the nondialyzable fractions were lyophilized, then $150 \mathrm{ml}$. of 1 per cent sodium chloride were added to each fraction which was then tested on a dog. The non-dialyzable material again produced shock (dog 129), while the dialyzable material did not (dog 126). An ammonium sulfate fractionation was done, therefore, on a $470 \mathrm{ml}$. aliquot to characterize more closely the shock-producing material. Table I summarizes this study. In order to determine whether the physiological activity of the pooled fluid decayed during storage on carbon dioxide snow, an aliquot of the original pooled fluid was again tested ( $\operatorname{dog} 136)$ and found to be active. In the protein fraction which salted out between 0.25 and 0.7 saturation there was $(a)$ the characteristic physiological response of the animal, which died in shock approximately 5 hours after injection of this fraction, (b) 84 per cent of the protein nitrogen, and $(c)$ all the detectable proteolytic activity. One may conclude that the toxic factors of the muscle exudate salt out in the $a$ and $\beta$ globulin and albumin range, and are probably not due to moities such as proteoses or peptones, which could be present in the muscle exudate as a result of muscle breakdown.

TABLE I

Fractionation of pooled muscle exudate (number 9)

\begin{tabular}{|c|c|c|c|c|}
\hline$\left(\mathrm{NH}_{4}\right)_{2} \mathrm{SO}_{4}$ concentration & $\underset{\text { ner }}{\text { Dog }}$ & Result & $\begin{array}{l}\text { Percent- } \\
\text { age of } \\
\text { protein } \\
\text { nitrogen } \\
\text { recovered }\end{array}$ & $\begin{array}{l}\text { Percent- } \\
\text { age of } \\
\text { enzymatic } \\
\text { activity } \\
\text { recovered }\end{array}$ \\
\hline $\begin{array}{l}0.25 \text { saturation } \\
0.25 \text { to } 0.70 \text { satura- } \\
\text { tion }\end{array}$ & $\begin{array}{l}131 \\
132\end{array}$ & $\begin{array}{c}\text { No effect } \\
\text { Died in } \\
\text { shock }\end{array}$ & $\begin{array}{r}4 \\
84\end{array}$ & $\begin{array}{r}0 \\
100\end{array}$ \\
\hline $\begin{array}{l}0.70 \text { to complete } \\
\text { saturation }\end{array}$ & 133 & No effect & 12 & 0 \\
\hline
\end{tabular}
$\frac{\text { enzymatic activity recovered }}{\text { enzymatic activity expected }}=79$ per cent.

4. Studies on proteolytic enzymes. The evidence from the fractionation studies served to focus attention on that group of proteins which is highly active physiologically, the enzymes. Since it was impossible to study the 50-odd enzymes known to be present in muscle (79), 1 group of enzymes was selected for study in the hope that this group of enzymes might serve as a tracer for muscle enzymes as a whole in the fractionation and toxicity correlation studies.

The proteolytic enzymes in muscle exudate were selected for investigation on the hypothesis that such enzymes might be activated under conditions of anoxia and might either produce toxic substances in situ or prove toxic when liberated into the general circulation. Proteolytic enzymes have been described in muscle beginning as far back as 1905 ( 80 to 83 ).

In addition to testing for activity at $\mathrm{pH} 5$, tests were made at other $\mathrm{pH}$ 's, ranging in some experiments up to $\mathrm{pH} 9$. Table II shows the effect 
TABLE II

Proteolytic enzymatic properties of muscle exudate

\begin{tabular}{|c|c|c|c|}
\hline Type of enzyme & Substrate & $\mathrm{pH}$ & Proteolytic coefficient \\
\hline $\begin{array}{l}\text { Aminopeptidase } \\
\text { Aminopeptidase or carboxypeptidase* } \\
\text { Aminopeptidase or carboxypeptidase* } \\
\text { Aminopeptidase or carboxypeptidase* } \\
\text { Aminopeptidase or carboxypeptidase* } \\
\text { Carboxypeptidase } \\
\text { Carboxypeptidase } \\
\text { Pepsinase } \\
\text { Trypsinase }\end{array}$ & $\begin{array}{l}\text { dl-leucinamide } \\
\text { 1-leucylglycylglycine } \\
\text { dl-leucylglycine } \\
\text { dl-alanylglycine } \\
\text { glycylglycine } \\
\text { cbz-glycyl-1-phenylalanine } \\
\text { cbz-1-leucylglycylglycine } \\
\text { cbz-glutamyl-tyrosine } \\
\text { benzoyl-1-argininamide }\end{array}$ & $\begin{array}{l}7.3 \\
7.6 \\
7.6 \\
6.6 \\
7.7 \\
5.4 \\
7.5 \\
5.5 \\
7.2 \\
7.8 \\
5.2 \\
7.7 \\
5.5 \\
8.0\end{array}$ & $\begin{aligned} & 1.6 \times 10^{-4} \\
& 5 \times 10^{-3} \\
& 1 \times 10^{-4} \\
& 3 \times 10^{-4} \\
& 3 \times 10^{-4} \\
& 0 \\
& 0 \\
& 0 \\
& 0 \\
& 0 \\
& 0 \\
& 0 \\
& 3 \times 10^{-8} \\
& 2 \times 10^{-6}\end{aligned}$ \\
\hline \multicolumn{4}{|c|}{ Proteolytic coefficient $=\frac{\mathrm{K}}{\mathrm{mgm} . \mathrm{PN} / \mathrm{ml} . \text { test solution }}$} \\
\hline
\end{tabular}

Cysteine was used as an added activator in the experiments run at $\mathrm{pH} 5$ range.

* A recent publication of Smith and Bergmann (84) describes a new type of enzymatic activity termed an imidoendopeptidase which can also hydrolyze these substrates.

of dog muscle exudate on a number of peptide substrates at varying $\mathrm{pH}$ 's. These substrates have been found (85) to characterize enzymatic activities more precisely than would be possible by means of protein substrates.

The presence of a trypsinase and of an aminoexopeptidase was found. More than 1 enzyme may well be responsible for splitting dl-leucylglycine, dl-leucinamide, 1-leucylglycylglycine, and dl-alanylglycine. For the present, however, there is definite evidence of the presence of 1 enzyme which can be designated, for convenience as an aminoexopeptidase. Other observations on this enzymatic activity as it appears in skin, subcutaneous tissue, lymph, and serum have been reported. (86). The possibility was considered that the enzyme might originate from plasma entering the damaged muscle rather than from the muscle substance itself. The level of activity is 5 to 10 times higher in muscle exudate, $\mathrm{h}$ ow ever, $\left(\mathrm{C}=5 \times 10^{-8}\right)$ than it is in plasma $(\mathrm{C}=0.6$ $\times\left(0^{-8}\right)$, which makes plasma an unlikely origin. Previous mention of the presence of the muscle trypsinase has not reached the authors' attention.

Since it was desirable to compare quantitatively the proteolytic acivity found in muscle exudates from different dogs, it was considered best to use the crude muscle exudate as a source of enzyme, rather than to introduce the possibility of artefacts due to enzyme concentration procedures.

The total amount of proteolytic activity (toward 1-leucylglycylglycine) was determined by multiplying the enzymatic activity constant per $\mathrm{ml}$. of muscle exudate by the total volume of muscle exudate. In this way, the total enzymatic activity in various muscle exudates could be compared, and an effort made to see if a correlation existed between the enzymatic activity of a muscle exudate and its toxicity toward an animal.

TABLE III

Negative correlation between toxicity and peptidase activity of muscle exudates

\begin{tabular}{c|c|c|c|c|l}
\hline \hline $\begin{array}{c}\text { Dog } \\
\text { number }\end{array}$ & Weight & $\begin{array}{c}\text { Volume } \\
\text { muscle } \\
\text { exudate }\end{array}$ & $\mathrm{K} \times 10^{* * * *}$ & $\frac{\mathrm{V} \times \mathrm{K} \times 10^{*}}{\mathrm{kgm} . \text { wt. }}$ & Result \\
\hline & $\mathrm{kgm}$. & & & & \\
147 & 20 & 135 & 20 & 135 & Survived \\
148 & 17.5 & 150 & 23 & 197 & Died \\
151 & 29 & 280 & 17 & 164 & Died \\
153 & 27.5 & 400 & 12 & 180 & Survived \\
154 & 23.5 & 565 & 8 & 195 & Died \\
178 & 7.8 & 70 & 28 & 250 & Survived \\
179 & 6 & 90 & 17 & 255 & Survived \\
$157^{*}$ & 16.3 & 193 & 16 & 195 & Survived \\
$144^{*}$ & 5.3 & 100 & 45 & 850 & Survived \\
$149^{* *}$ & 9.8 & 50 & 23 & 117 & Died \\
\hline
\end{tabular}

* These dogs were given saline extracts of muscle. ** This dog was given heterologous muscle exudate. *** Substrate Lleucylglycylglycine. 
Muscle exudates, therefore, were collected from 7 dogs, and were reinjected in each case intravenously into the same animal from which the fluid was collected. Four of the animals died, and 3 survived. Table III shows that the total amount of proteolytic activity per kgm. of dog reinjected was no greater in the animals which died than in those which survived.

From normal dog muscle, a concentrate of the aminoexopeptidase was prepared which contained 5 times the total amount of aminoexopeptidase found in any of the exudates. Upon injection by slow intravenous drip into 2 normal dogs under sodium pentobarbital anesthesia, no deleterious effect upon the blood pressure, temperature, pulse, or respiration was observed during a subsequent 6-hour period.

The plasma concentration of aminoexopeptidase was followed in $1 \mathrm{dog}$. It remained constant $\left(\mathrm{K}=2.1-2.3 \times 10^{-3}\right)$ until after the reinjection of the muscle exudate, and it was found 5 hours after this reinjection to be 4 times its previous level $\left(K=8 \times 10^{-3}\right)$.

\section{DISCUSSION}

An effort has been made to isolate the toxic factor (or factors) present in certain exudates from anoxic muscle. A study of the electrolyte pattern indicated that potassium and other electrolytes were disturbed but probably not sufficiently to cause shock. Results of dialysis and fractionation with ammonium sulfate pointed toward proteins as containing the toxic substance. Muscle enzymes were suspected, and the proteolytic group of enzymes was investigated. Proteolytic enzymes were demonstrated in the muscle exudates but were found not to be the toxic factor. A saline extract of fresh muscle was found not to be toxic.

These considerations led to the conclusion that some toxic protein component was introduced in- to certain exudates of anoxic muscle which was not present in extracts of normal muscle. This point of view has directed our attention toward the products of metabolism of the bacteria frequently associated with a noxic, traumatized muscle.

\section{SUM MARY}

A study has been made of the fluid which exudes from muscles previously kept anoxic for 5 hours. Some of these exudates produce shock when injected into an animal.

1. There is evidence that this anoxia results in a leakage into the surrounding tissue spaces of intracellular components of the muscle, including proteins and electrolytes. The chemical constitution and electrophoretic patterns of the exudate have been described.

2. The toxic properties of a collection of pooled muscle exudates were contained in the non-dialyzable fraction, could be salted out between 0.25 and 0.7 saturation with ammonium sulfate, and therefore, are probably protein in nature.

3. At least 2 proteolytic enzymes have been found in muscle exudates. One of these, tentatively classified as an aminoexopeptidase, is present in high concentration. This same enzymatic activity can be found in extracts of normal dog muscles. When given intravenously to dogs, a concentrate of this enzyme produced no marked deleterious effect, and the shock-producing effects of individual muscle exudates did not correlate with their peptidase content. The second enzyme found in muscle exudate hydrolyzes benzoyl-1argininamide, and may be termed a trypsinase.

The authors are indebted to the late Dr. Max Bergmann for the carbobenzoxy-1-glutamyl-1-tyrosine and the carbobenzoxyglycyl-1-phenylalanine. They are indebted to Dr. M. S. Dunn and the Amino Acid Manufacturers, Los Angeles, California, for supplies of dl-leucylglycine, glycylglycine, dl-alanylglycine, and 1-leucylglycylglycine.

Bibliography follows Paper VI of this series. 